\title{
ICAM $^{-}$MELANOMA CELLS ARE RELATIVELY RESISTANT TO CD3-MEDIATED T-CELL LYSIS
}

Eric Braakman ${ }^{1}$, Peter S. Goedegebuure ${ }^{1}$, Rea J. Vreugdenhil ${ }^{1}$, David M. Segal ${ }^{3}$, Stephen Shaw ${ }^{3}$ and Reinder L.H. BoLHUIS ${ }^{1,2,4}$

${ }^{1}$ Dept. of Immunology, Dr. Daniel den Hoed Cancer Center, Rotterdam; ${ }^{2}$ Radiobiological Institute, TNO Health Organization, Rijswijk, The Netherlands; and ${ }^{3}$ Experimental Immunology Branch, National Cancer Institute, Bethesda MD, USA.

The primary activation pathway of $\mathbf{T}$ cells is via the T-cell receptor (TCR)/CD3 complex, which is functionally interrelaced with various accessory molecules. We examined the contribution of the lymphocyte-function-associated antigenI/intercellular adhesion molecule I (LFA-I/ICAM-I) interaction to CD3/TCR-mediated lysis by cytotoxic T lymphocytes (CTL). We used ICAM-I-ort tumor cell lines as target cells and anti-CD3- or anti-LFA-I containing hetero-cross-linked monoclonal antibody (MAb) to bridge CTL and target cells and simultaneously to activate CTL. The ICAM-I- melanoma-derived cell line $\lg R 39$ was relatively resistant to $C D 3$ mediated lysis by both TCR $\alpha \beta^{+}$and TCR $\gamma \delta^{+}$CTL, when compared with ICAM-I+ cell lines. Induction of ICAM-I on the membrane of $\operatorname{lgR} 39$ cells by tumor necrosis factor (TNF) rendered these cells more susceptible to $C D 3$-mediated lysis. Anti-ICAM-I MAb inhibited this TNF-enhanced susceptibility to lysis, directly demonstrating that the induction of ICAM-I was critical in the TNF-induced increase in susceptibility to lysis of IgR39 cells. CTL formed less efficient conjugates with the ICAM-I- cells as compared to ICAM-I+ cells. Both spontaneous and CD3-induced conjugate formation as well as CD3-mediated lysis of ICAM-I- tumor cells by CTL were enhanced by the addition of anti-LFA-I containing heterocross-linked MAb, thereby mimicking the LFA-I/ICAM-I interaction between CTL and target cells. Soluble anti-CD 18 MAb inhibited CD3-mediated lysis of ICAM-I- target cells by CTL without affecting their conjugate formation. Anti-LFA-I MAb added after conjugate formation still inhibited lysis of both ICAM-I+or- tumor cells. Taken together, these findings suggest that the LFA-I/ICAM-I interaction co-activates CD3/ TCR-mediated lysis by CTL through both an enhanced CTLtarget cell binding and the delivery of post-conjugate costimulatory signals.

$T$ cells can be activated by the antigen-specific T-cell receptor (TCR) interacting with non-self major histocompatibility complex (MHC) proteins or foreign antigen associated with self MHC proteins (Ashwell and Schwartz, 1986; Martz, 1977). Lymphocytes may also be activated via non-polymorphic cell-surface receptors such as CD2, CD3 or CD16 interacting with their ligands or monoclonal antibody (MAb) (Meuer et al., 1984; Bolhuis et al., 1986; Van de Griend et al., 1987). Recent evidence suggests that these activation sites are functionally interrelated, for instance, activation via CD2 can be regulated via CD3 and vice versa (Van de Griend et al., 1987; Goedegebuure et al., 1989).

The interaction between cytotoxic T lymphocytes (CTL) and the relevant target cells results in target-cell lysis by a multistep process (Martz, 1977; Mentzer et al., 1987). The initial adhesion step is the rapid formation of an intercellular bond (conjugate formation) which is antigen-independent. Two major pathways of adhesion have been identified. First, lymphocyte-function-associated antigen-1 (LFA-1) on CTL interacts with intercellular adhesion molecule-1 (ICAM-1) on the target cell (Shaw et al., 1986; Makgoba et al., 1988a). Second, the effector cell CD2 interacts with LFA-3 on the target cell (Selvaraj et al., 1987; Dustin et al., 1987; Takai et al., 1987; Hunig et al., 1987). Subsequently, antigen recognition via the TCR results in triggering of the CTL lytic machinery and target-cell lysis (Martz, 1977).

LFA-1 is a trans-membrane heterodimer composed of a 180-
$\mathrm{kDa} \alpha$ chain (CD11a) and a $95-\mathrm{kDa} \beta$ chain (CD18) which is expressed by most leukocytes (Springer et al., 1987; Martz, 1987; Krensky et al., 1983). In addition to its adhesion function, LFA-1 is also thought to be involved in T-cell activation, possibly as a signal transduction molecule, as reported for CD2 (Hunig et al., 1987). Binding of anti-LFA-1 $\alpha$ or anti-LFA-1 $\beta$ MAbs to $T$ cells has been shown to up- or down-regulate, respectively, anti-CD3 MAb-triggered T-cell proliferation in the absence of intercellular adhesion (Van Noesel et al., 1988). In mice, anti-LFA- $1 \alpha$ MAb enhances proliferative responses of pre-activated $\mathrm{T}$ and B lymphocytes (Pircher et al., 1986; Mishra et al., 1986). Finally, a unique anti-LFA-1 $\alpha$ MAb induces homotypic cell-cell interactions (Keizer et al., 1988).

ICAM-1 is a monomeric $90-114-\mathrm{kDa}$ glycoprotein which can be expressed on cells of many lineages, especially at specific differentiation stages or after exposure of cells to certain inflammatory mediators in vitro or in vivo (Dustin et al., 1986). Biochemical and functional studies have conclusively demonstrated that ICAM-1 is one of the ligands for LFA-1 (Makgoba et al., 1988a,b; Marlin and Springer, 1987; Simmons et al., 1988; Rothlein et al., 1986). Target-cell ICAM-1 is involved in adhesion to and lysis of target cells; however, demonstration of this role is restricted to target cells which express ICAM-1 as the major LFA-1 ligand (Makgoba et al., $1988 b$ ). Furthermore, ICAM-1 is a major contributor to a variety of other $\mathrm{T}$-cell responses dependent on cell-cell interaction (Boyd et al., 1988; Dougherty et al., 1988; Altmann et al., 1989; Schulz et al., 1988). A previously suggested second ligand for LFA-1, i.e., ICAM-2, has been identified (Staunton et al., 1989). However, at this point it is unclear whether binding of the LFA-1 to the ICAM-1 ligand molecule not only facilitates the adhesion of the effector cell to the target cell, but also mediates signals that regulate CTL activation.

Lysis-resistant Burkitt's lymphoma cells express low levels of LFA-1, LFA-3 and ICAM-1 (Gregory et al., 1988a; Billaud et al., 1987). Epstein-Barr virus (EBV)-positive biopsy cells with a low expression of these molecules are relatively resistant to lysis by specific CTL. Prolonged in vitro culture of these cells induces an increased expression of the molecules which is associated with a more efficient interaction with specific CTL. These findings prompted speculation that the lack of expression of ICAM-1 and other adhesion molecules on tumor cells contributes to their escape from immunosurveillance (Gregory et al., 1988a,b; Clayberger et al., 1987).

The importance of the LFA-1/ICAM-1 interaction led us to further study its involvement in CTL/target-cell conjugate formation and triggering of lysis. To this end, we used ICAM1-positive or -negative tumor-cell lines as target cells and bispecific $\mathrm{Ab}$-heteroconjugates, containing an anti-CD3 $\mathrm{MAb}$

${ }^{4}$ To whom correspondence and reprint requests should be sent, at Dept of Immunology, Dr. Daniel den Hoed Cancer Center, P.O. Box 5201, 3008 AE Rotterdam, The Netherlands.

Received: March 6, 1990. 
which is covalently coupled to an anti-DNP antibody. Such bispecific reagents efficiently bridge effector cells and trinitrobenzene sulfonate (TNP)-modified target cells and simultaneously trigger the lytic machinery of the effector cell (Goedegebuure et al., 1989; Karpovsky et al., 1984). Our data demonstrate that induction of ICAM-1 expression on target cells enhances their susceptibility to CD3-triggered lysis. Associated findings suggest that this co-stimulatory effect results from enhanced conjugate formation as well as enhanced signal transduction by LFA-1/ICAM-1 interactions.

\section{MATERIAL AND METHODS}

\section{Cytotoxic clones}

CTL clones were obtained by limiting dilution cloning under polyclonal activation conditions as we described earlier (Van de Griend et al., 1987). In short, CTL clones were expanded in 96-well round-bottomed microtiter plates (Greiner Labor Technik, Phidelsheim, FRG). One to $3 \times 10^{3}$ cloned CTL per well were stimulated with a mixture of irradiated $(25 \mathrm{~Gy})$ allogeneic PBL $\left(2 \times 10^{4}\right)$ and $1 \times 10^{4}$ Epstein-Barr virus (EBV)-transformed lymphoblastoid B-cell lines (BSM and APD) in a final volume of $200 \mu$. The culture medium was RPMI 1640 (Flow Laboratories, Rockville, MD) buffered with bicarbonate $(2 \mathrm{~g} / \mathrm{l})$ and HEPES $(4.8 \mathrm{~g} / \mathrm{l})$ and supplemented with $10 \%$ non-heat-inactivated (pooled) human serum, $25 \mathrm{U} / \mathrm{ml}$ recombinant IL-2 (EuroCetus, Amsterdam, The Netherlands), 4 $\mathrm{mm}$ glutamine, $100 \mathrm{IU} / \mathrm{ml}$ penicillin and streptomycin, $1 \mu \mathrm{g} / \mathrm{ml}$ indomethacin and $1 \mu \mathrm{g} / \mathrm{ml}$ leukoagglutinin (HA15, Pharmacia, Uppsala, Sweden). Clones were harvested and replated with new feeder cells and fresh medium at weekly intervals.

\section{Antibodies}

Bispecific hetero-cross-linked antibodies (Abs) were prepared with the use of the cross-linking reagent $\mathrm{N}$-succinimidyl-3-(2-pyridyldithiol propionate) (SPDP) as described in detail elsewhere (Karpovsky et al., 1984). Hetero-cross-linked Abs used in this study were: anti-CD3 (OKT3) $\times$ anti-DNP; anti-CD18 (MHM23) $\times$ anti-DNP and anti-HLA Class I $(\mathrm{W6} / 32) \times$ anti-DNP MAb. Anti-DNP Abs were purified polyclonal rabbit Abs. MAbs used for the inhibition of lymphocyte functions and for immunofluorescence staining were: CLB54 (anti-CD18) (Miedema et al., 1984), specific for the LFA- $1 \beta$ chain, a generous gift from Dr. R.A.W. van Lier (CLB, Amsterdam, The Netherlands); MAb 84H10 (antiICAM-1) (Makgoba et al., 1988a) and W6/32 (anti-HLA Class-I common epitope) (Barnstable et al., 1978).

\section{Cytotoxicity assay}

Cytotoxic activity was measured in a standard 3-hr ${ }^{51} \mathrm{Cr}$ release assay (Van de Griend et al., 1987; Goedegebuure et al., 1989). Briefly, varying numbers of effector cells were added in triplicate in $75 \mu \mathrm{l} /$ well in 96-well round-bottomed microtiter plates. The hetero-cross-linked $\mathrm{Ab}(75 \mu \mathrm{l})$ was added to the microtiter well at the indicated concentrations 30 min before addition of ${ }^{51} \mathrm{Cr}$-labelled target cells $(100 \mu \mathrm{l})$. Target cells were incubated with $0.3 \mathrm{~mm}$ trinitrobenzene sulfonate (TNP) for $15 \mathrm{~min}$ at $37^{\circ} \mathrm{C}$ and then washed. ICAM-1 expression on IgR39 tumor cells was enhanced by incubation with $1000 \mathrm{U} / \mathrm{ml}$ recombinant human tumor necrosis factor (recTNF) (Cetus Corp., Emeryville, CA) for $24 \mathrm{~h}$. Tumor cell lines used as target cells in this study include IgR39 and IgR37, melanoma-derived cell lines: Licr-Lon, a leukemic plasma cell line: Molt-4, a T-cell line, APD, an EBV-transformed B-cell line: K562, an erythromyeloid cell line and U937, a monocytic cell line (Van de Griend et al., 1987).

Hetero-cross-linked Ab-induced cytotoxicity was blocked with MAb by the simultaneous addition of $50 \mu$ l blocking MAb and $50 \mu \mathrm{l}$ heteroconjugated $\mathrm{Ab}$ to $50 \mu \mathrm{l}$ effector cells $30 \mathrm{~min}$ prior to the addition of $100 \mu \mathrm{l}$ target cells, unless indicated otherwise. The standard error of the mean percentage lysis never exceeded $5 \%$ and was omitted for clarity of presentation.

\section{Conjugate formation assay}

Antigen-independent and hetero-cross-linked Ab-induced conjugate formation of CTL and target cells was assessed by FACS analysis (Becton Dickinson, Mountain View, CA) (Makgoba et al., 1988a; Perez et al., 1985; Leo et al., 1987). CTL $\left(5 \times 10^{6}\right)$ were labelled with $100 \mu \mathrm{g} / \mathrm{ml}$ hydroethidine in a volume of $2 \mathrm{ml}$ at $37^{\circ} \mathrm{C}$ for $25 \mathrm{~min}$. Target cells $\left(5 \times 10^{6}\right)$ were first modified with TNP (see above) and then labelled with $0.05 \mu \mathrm{g} / \mathrm{ml}$ carboxy fluorescein diacetate (CFDA) in a volume of $2 \mathrm{ml} \mathrm{at} 37^{\circ} \mathrm{C}$ for $25 \mathrm{~min}$. CTL and target cells were washed before use. Twenty microliters of labelled effector cells $\left(10^{7} / \mathrm{ml}\right)$ were mixed with an equal amount of labelled target cells $\left(10^{7} / \mathrm{ml}\right)$ with and without Ab-heteroconjugates and/or blocking MAb. Ab-heteroconjugates and MAb were preincubated with the CTL for $15 \mathrm{~min}$ at $37^{\circ} \mathrm{C}$ before the addition of tumor target cells. The final volume was adjusted to $100 \mu \mathrm{l}$. Conjugate assay medium was RPMI 1640 supplemented with $10 \%$ FCS. CTL and target-cell mixtures were centrifuged for $5 \mathrm{sec}$ in a serofuge and conjugates were allowed to form at $21^{\circ} \mathrm{C}$ for $10 \mathrm{~min}$. Conjugate formation was stopped by the addition of $1 \mathrm{ml}$ ice-cold PBS $+1 \%$ BSA. Cells were immediately resuspended and analyzed on a FACScan. Ten thousand total fluorescent events were collected and the number of events simultaneously emitting red and green fluorescence (conjugates) was divided by the total number of events emitting red fluorescence (total effector cells) yielding the percentage of CTL that had formed conjugates. No conjugates were observed when CTL and target cells were mixed and analyzed immediately.

\section{Immunofluorescence assay}

Five hundred thousand cells were pelleted and incubated with 10-20 $\mu \mathrm{l} \mathrm{MAb}$ at $4^{\circ} \mathrm{C}$ for $30 \mathrm{~min}$. After washing, the cells were incubated with $10 \mu l$ 1:40 diluted goat anti-mouse, conjugated with FITC (Nordic, Tilburg, The Netherlands). The cells were washed twice with PBS $+1 \%$ BSA $+0.01 \%$ sodium azide and analyzed on the FACScan.

\section{RESULTS}

\section{Melanoma IgR39 is relatively resistant to CD3-mediated lysis}

A panel of histologically distinct tumor cell lines were compared in their susceptibility to lysis by $\mathrm{TCR} \alpha \beta^{+} / \mathrm{CD} 3^{+}$and TCR $\gamma \delta \delta^{+} / \mathrm{CD}^{+} \mathrm{CTL}$ clones triggered via CD3, using heterocross-linked anti-CD $3 \times$ anti-DNP. Most tumor cell lines were susceptible to CD3-mediated lysis (Fig. 1). The melanoma-derived cell line IgR39, however, showed a relative resistance to CD3-mediated lysis. This was found for both TCR $\alpha \beta^{+}$and TCR $\gamma \delta^{+}$CTL and hence is independent of the sublineage of the CTL.

The level of CD3-mediated lysis depended on the amount of anti-CD3 added. At higher anti-CD3 concentrations $(15 \mathrm{ng} / \mathrm{ml}$ or more) the tumor-cell line IgR39 was effectively lysed (Fig. $1)$. Thus, the relative resistance to CD3-mediated lysis of IgR39 melanoma cells by cloned TCR $\alpha \beta^{+}$and TCR $\gamma \delta^{+}$CTL can be overcome at higher effective densities of anti-CD3 MAb on the target cells.

\section{Expression of cellular adhesion molecules on tumor cells}

Because the relative resistance of IgR39 melanoma cells to CD3-mediated lysis was independent of the type of CTL clone used, we hypothesized that the composition of surface molecules on the target cells, particularly the known ligands for CTL/target-cell interaction ICAM-1 and LFA-3, determined its relative resistance to CD3-mediated lysis by CTL. The TNP 


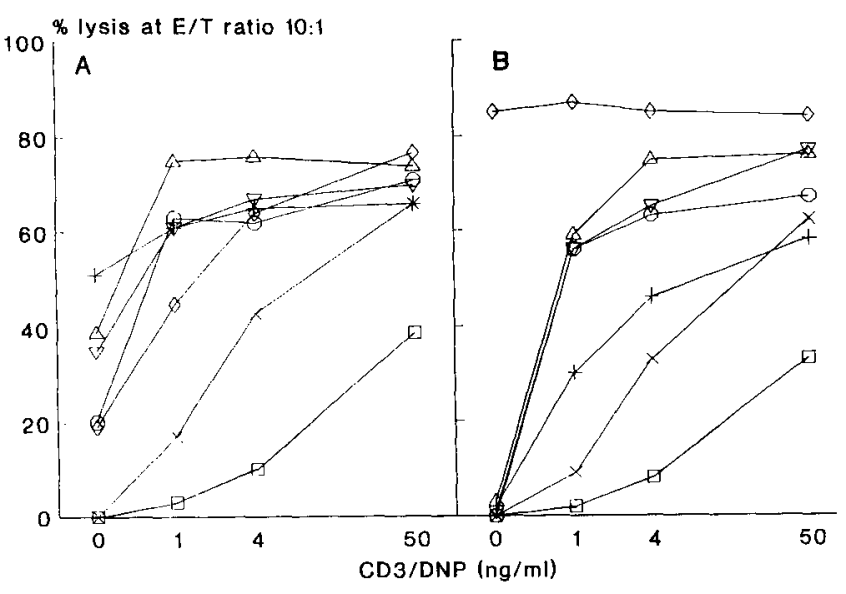

FigURE 1 - IgR39 melanoma cell line is relatively resistant to $\mathrm{CD} 3$ mediated lysis by TCR $\gamma \delta^{+} / \mathrm{CD} 3^{+}$clone WiK (panel $a$ ) or TCR $\alpha \beta^{+} / \mathrm{CD}^{+}$clone D11 (panel $b$ ). TNP-modified tumor cell lines used as target cells were: $\square$, IgR39; + , IgR37; X, APD; $\triangle$, Molt-4; $\diamond$, Licr-Lon; $\nabla, \mathrm{K} 562$ and $O$, U937. Target-cell lysis was induced by addition of the indicated concentration hetero-cross-linked anti-CD3 MAb. Target-cell line Licr-Lon expressed the HLA Class-I antigen (Cw3), specifically recognized by $\operatorname{TCR} \alpha \beta^{+} / \mathrm{CD} 3^{+}$clone D11.

modification of the IgR39 cells was not the cause of the relative resistance because IgR39 target cells reportedly showed levels of sensitivity to CD2-mediated lysis comparable to those of other tumor cell lines (Goedegebuure et al., 1989). The expression of LFA-3 and ICAM-1 on the tumor cell lines was then determined. Contrary to the panel of other cultured tumor cells tested in Figure 1, the IgR39 cells lacked surface expression of ICAM-1 (Fig. 2). All human tumor cell lines tested here expressed LFA-3. TNP modification of the tumor cell lines did not affect expression of ICAM-1 and LFA-3 (data not shown).

The "resistance" of IgR39 target cells to CD3-mediated lysis is due to lack of ICAM-I expression

To assess the functional correlation between lack of ICAM-1 expression and "resistance" to CD3-mediated lysis, we used
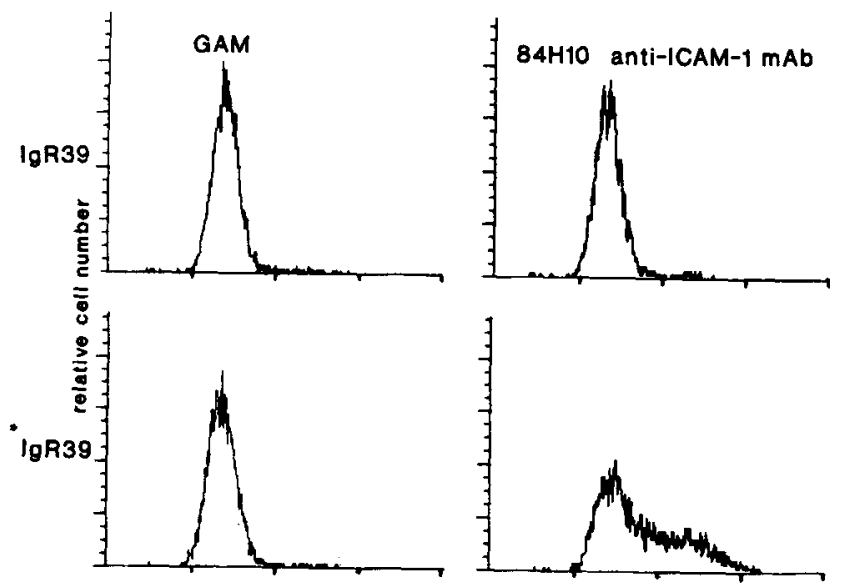

Log fluorescence intenaity

. $1000 \mathrm{U} / \mathrm{ml}$ rTNF tor $24 \mathrm{hr}$

FIGURE 2 - TNF induces ICAM-1 expression on the ICAM-1melanoma cell line IgR39. IgR39 was cultured in the presence of 1000 $\mathrm{U} / \mathrm{ml}$ recTNF for $24 \mathrm{hr}$.
TNF which is known to induce ICAM-1 expression on many cell types (Dustin et al., 1986). Incubation of IgR39 cells with $1000 \mathrm{U} / \mathrm{ml}$ recTNF for $24 \mathrm{hr}$ induced ICAM-1 expression as determined by FACS-analysis (Fig. 2). This expression of ICAM-1 was accompanied by a simultaneous increase in susceptibility to CD3-mediated lysis (Fig. 3). Further evidence that ICAM- 1 is the critical factor determining the susceptibility to CD3-mediated lysis of IgR39 target cells comes from antiICAM-1 MAb inhibition studies. ICAM-1 specific MAb again abolished the increased levels of CD3-mediated lysis of IgR39 target cells obtained by TNF treatment (Fig. 3). Indeed, the level of lysis of TNF-untreated ICAM-1 ${ }^{-}$IgR39 cells was, as expected, not affected by anti-ICAM-1 MAb. Thus, TNFinduced expression of ICAM-1 can account for the TNFinduced increase in susceptibility of IgR39 target cells to CD3mediated CTL lysis.

\section{Signalling properties of LFA-1 in CTL activation}

To examine the signalling abilities of LFA-1 in the activation of the lytic machinery of CTL, we tested the effect of anti-CD18 (LFA-1 $\beta$ ) MAb on spontaneous and anti-CD3 MAb induced conjugate formation and cytolysis. As shown in Table I, anti-CD18 MAb, as expected, inhibited spontaneous conjugate formation of CTL with ICAM-1 + Licr-Lon cells but minimally with ICAM-1 - IgR39 cells. The latter also suggests that ICAM-1 ${ }^{-}$IgR39 cells lack sufficient expression of alternative ligands for LFA-1 (e.g. ICAM-2) (Staunton et al., 1989). Anti-CD3 MAb containing heteroconjugated $\mathrm{Ab}$ enhanced the percentage conjugates formed between CTL and tumor cells. CD18-specific MAb had virtually no inhibitory effect on CD3mediated conjugate formation of CTL to ICAM-1 +or- tumor cells (Table N), but did inhibit CD3-mediated lysis of either ICAM-1 +or- target cells (Fig. 4). Interestingly, this significant inhibitory effect of CD18-specific MAb on lysis contrasts with the marginal inhibitory effects on conjugate formation. These findings point to a regulatory role for LFA-1 in CD3mediated CTL activation post CTL/target-cell conjugate formation.

\section{Anti-CD18 $\times$ anti-DNP hetero-cross-linked Ab coactivates} CD3-mediated lysis of ICAM-1- $1^{-}$target cells

Experiments were designed to mimic LFA-1/ICAM-1 inter-

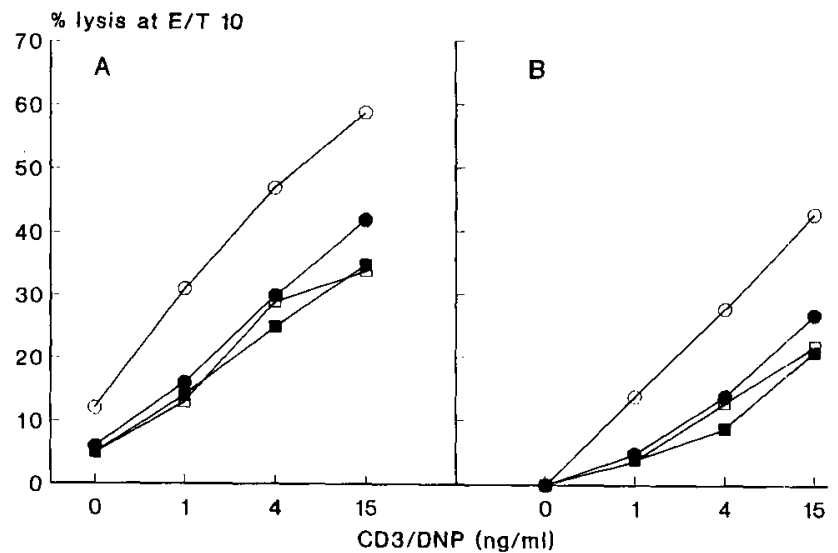

FIGURE 3 - Anti-ICAM-1 MAb abolishes the increased susceptibility of TNF-treated IgR39 cells to CD3-mediated lysis by $\mathrm{TCR} \gamma \delta^{+} / \mathrm{CD}^{+}$clone WiK (panel $a$ ) and TCR $\alpha \beta^{+} / \mathrm{CD}^{+}$clone $\mathrm{D} 11$ (panel b). IgR39 cells were cultured with or without $1,000 \mathrm{U} / \mathrm{ml}$ recTNF for $24 \mathrm{hr}$ and TNP-modified before use as target cells. Heterocross-linked anti-CD3 MAb and anti-ICAM-1 MAb (84 HI0, dilution $1 / 1,000$ of ascites) were added simultaneously to the CTL effectors prior to the addition of target cells $\square, \operatorname{IgR} 39, \mathbf{Z}, \operatorname{IgR} 39$ + anti-ICAM-1 MAb; $O$, TNF-treated IgR39 and $O$, TNF-treated IgR39 + anti-ICAM-1 MAb. 
TABLE I - INHIBITION OF CONJUGATE FORMATION BY ANTI-CD18 (LFA-1ß) MAb

\begin{tabular}{|c|c|c|c|}
\hline \multirow{2}{*}{$\begin{array}{c}\text { Addition of } \\
\text { heteroconjugate }^{2}\end{array}$} & \multirow{2}{*}{$\underset{\mathrm{MAb}^{3}}{\text { Anti-CD } 18}$} & \multicolumn{2}{|c|}{$\begin{array}{c}\text { Percentage conjugates } \\
\text { between TCR } \delta^{+} \delta^{+} \mathrm{CTL}^{1} \text { and } \\
\text { TNP-target cells }\end{array}$} \\
\hline & & $\begin{array}{l}\text { ICAM-1 } \\
\text { (Licr-Lon) }\end{array}$ & $\begin{array}{r}\text { ICAM-1 - } \\
\text { (IgR39) }\end{array}$ \\
\hline - & - & 34 & 23 \\
\hline- & + & 17 & 19 \\
\hline $\begin{array}{l}\text { Anti-CD3 } \\
\times \text { anti-DNP }\end{array}$ & - & 52 & 35 \\
\hline $\begin{array}{l}\text { Anti-CD3 } \\
\quad \times \text { anti-DNP }\end{array}$ & + & 48 & 31 \\
\hline
\end{tabular}

${ }^{1} \mathrm{TCR} \gamma \delta^{+}$effector cell: WiK.- ${ }^{2}$ Heteroconjugate concentration $1 \mu \mathrm{g} / \mathrm{ml}$. $-{ }^{3}$ Anti-CD18 (CLB54 ascites, 1/1000). $-{ }^{4}$ For calculation of percentage conjugates see "Material and Methods".
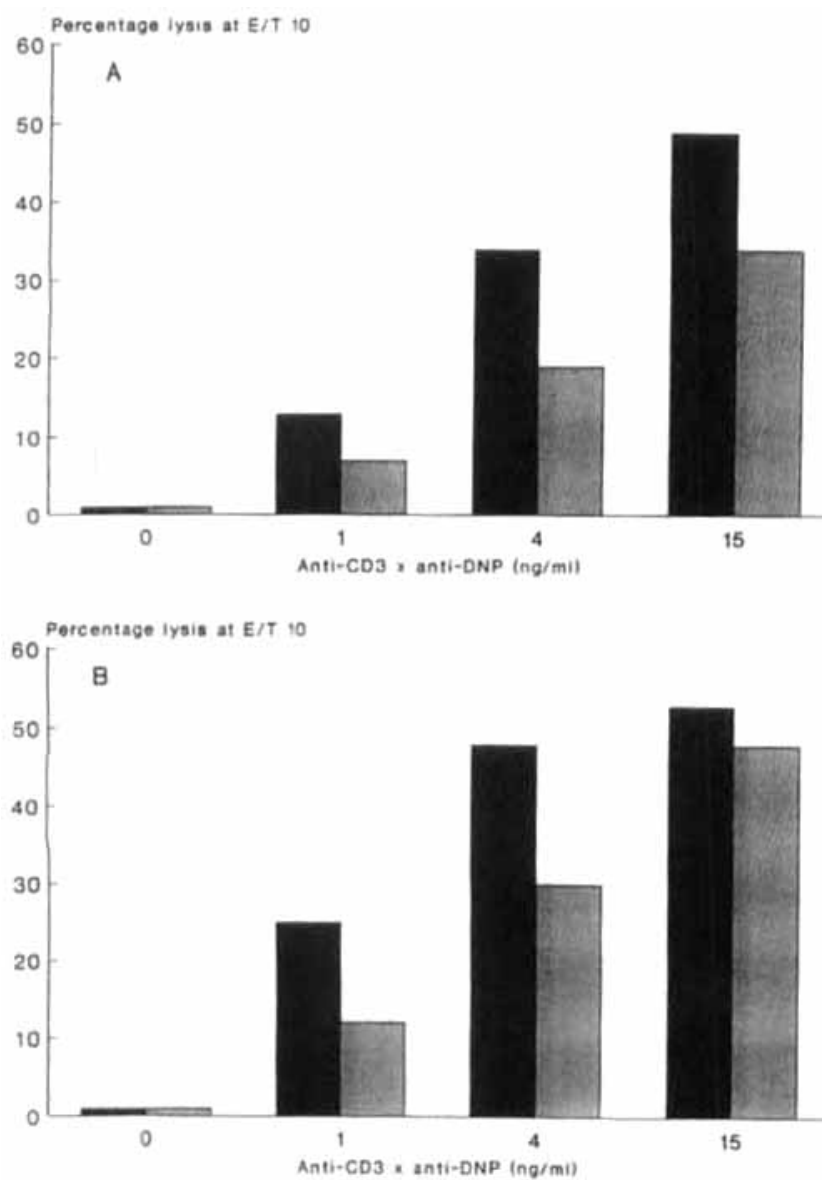

Figure 4 - Anti-CD18 MAb inhibits CD3-mediated lysis of ICAM-1 ${ }^{-}$IgR39 cells (panel $a$ ) or ICAM-1 ${ }^{+}$Licr-Lon cells (panel $b$ ) by TCR $\gamma \delta^{+} / \mathrm{CD3}^{+}$clone WiK. Target-cell lysis is induced by the indicated concentration of anti-CD3 MAb in the absence (solid bars) or presence (hatched hars) of anti-CD18 MAb (CLB54, 1/1000 of ascites).

actions, using anti-CD18 $\times$ anti-DNP hetero-cross-linked $\mathrm{Ab}$. Addition of anti-CD18 $\times$ anti-DNP Ab-heteroconjugate increased the susceptibility of ICAM-1- IgR39 target cells to CD3-mediated lysis by TCR $\alpha \beta^{+}$CTL (Table II). Similar results were obtained using TCR $\gamma \delta+$ CTL (Table III). The susceptibility to lysis of ICAM-1 ${ }^{+}$target cells was much less affected (Table III). Remarkably, anti-CD18 $\times$ anti-DNP Ab alone also considerably enhanced the MHC-unrestricted lysis of ICAM-1 - but not ICAM-1 ${ }^{+}$target cells by TCR $\gamma \delta^{+}$CTL. Control, anti-HLA Class I $\times$ anti-DNP $A b$ had no effect on MHC-unrestricted or CD3-mediated lysis.
TABLE II - ANTI-CD18 $\times$ ANTI-DNP Ab CO-ACTIVATES LYSIS OF ICAM-1 TARGET CELL BY TCR $\alpha \beta$ CTL

\begin{tabular}{ccc}
$\begin{array}{c}\text { Addition of } \\
\text { Ab heteroconjugates }\end{array}$ & \multicolumn{2}{c}{$\begin{array}{c}\text { Percentage lysis of ICAM-1 } \\
\text { IgR39 by TCR } \alpha \beta^{+} \text {clones }\end{array}$} \\
\cline { 2 - 3 }- & 1 & Clone 75 \\
aCD18 $\times$ aDNP & 0 & 0 \\
aCD3 $\times$ aDNP & 37 & 0 \\
aCD3 $\times$ aDNP & 70 & 37 \\
+ & & 68 \\
\hline
\end{tabular}

Effector to target cell ratio of 7 (clone D11), 14 (clone 75). Heteroconjugate concentration aCD3 $\times$ aDNP $25 \mu \mathrm{g} / \mathrm{ml}$; aCD18 $\times$ aDNP $25 \mu \mathrm{g} / \mathrm{ml}$.

\section{DISCUSSION}

Initiation of CD3/TCR complex-mediated T-cell functions is believed to be interrelated with various accessory molecules. The transmembrane molecule LFA-1 is one of the most important accessory molecules. Here, we have studied the contribution of the LFA-1/ICAM-1 interaction to CD3/TCR complex-mediated lysis by TCR $\alpha \beta^{+}$and TCR $\gamma \delta^{+}$CTL at different stages of the lytic cycle. The use of hetero-cross-linked anti-CD3 $\times$ anti-DNP $\mathrm{Ab}$ makes it possible to compare the susceptibilities to lysis of different tumor cell lines by an individual CTL clone. An ICAM-1- melanoma tumor cell line IgR39 shows a relative resistance to CD3/TCR-mediated cytolysis by $\mathrm{TCR} \alpha \beta^{+}$as well as by TCR $\gamma \delta^{+}$cloned lymphocytes. The low susceptibility of IgR39 tumor cells to CD3/ TCR-mediated cytolysis was directly related to the lack of ICAM-1 expression because TNF treatment of ICAM-1IgR39 cells induced ICAM-1 expression and indeed simultaneously increased susceptibility to CD3/TCR-mediated cytolysis. The IgR39 cell line is not sensitive to TNF lysis (data not shown). Moreover, anti-ICAM-1 MAb down-regulated this TNF-induced, increased susceptibility to lysis, demonstrating that it was functionally due to up-regulation of ICAM-1 and not other unknown ligands.

The relative resistance of IgR39 cells to CD3-mediated cytolysis can be overcome by higher concentrations of anti-CD3 $\mathrm{MAb}$. Thus, an efficient LFA-1/ICAM-1 interaction may lower the requirement for either high antigen density on target cells or, alternatively, may compensate for a low-affinity TCR on CTL by establishing a more effective CTL-target-cell interaction.

The interaction between CTL and target cells, resulting in target cell lysis, is a multi-step process (Martz, 1977; Mentzer et al., 1987). Thus the relative resistance of the ICAM-1IgR39 target cells to CD3/TCR-mediated lysis may reflect either a less efficient conjugate formation, or a decreased level of activation of the lytic machinery. This study shows that CTL formed conjugates less efficiently with ICAM-1 - than with ICAM-1 + tumor cells. Hetero-cross-linked anti-CD3 MAb enhanced conjugate formation with both the ICAM-1-negative and -positive target cells. Addition of anti-CD18 $\times$ anti-DNP $\mathrm{Ab}$ increased spontaneous and CD3-mediated conjugate formation with the ICAM-1 - cell line and consequently enhanced CD3/TCR-mediated lysis of this target cell. Hetero-crosslinked anti-CD18 MAb failed to enhance CD3/TCR-mediated lysis of ICAM-1 + tumor cells, because it could not further enhance the relatively efficient conjugate formation with this target. It was remarkable that hetero-cross-linked anti-HLA Class I did not enhance CD3-mediated conjugate formation with the ICAM-1 - target cells (data not shown) and therefore did not affect CD3-mediated lysis.

Our data suggest that the relative resistance to CD3mediated lysis of the ICAM-1 - tumor cells is not exclusively associated with decreased conjugate formation. The LFA1/ICAM-1 interaction also appears to synergize with CD3/ 
LFA-1 CO-ACTIVATES TCR-MEDIATED TUMOR-CELL LYSIS

TABLE III - ANTI-CD18 $\times$ ANTI-DNP Ab CO-ACTIVATES LYSIS OF THE ICAM-1 ${ }^{-}$TARGET CELL BY TCR $\gamma \delta$ CTL

\begin{tabular}{|c|c|c|c|c|c|c|c|c|c|c|}
\hline & \multirow{2}{*}{\multicolumn{2}{|c|}{$\frac{\mathrm{Ab}}{\text { heteroconjugates }^{1}}$}} & \multicolumn{4}{|c|}{ ICAM-1 $^{-}($IgR39) } & \multicolumn{4}{|c|}{ ICAM-1 $^{+}$(Licr-Lon) } \\
\hline & & & Exp. 1 & Exp. 2 & Exp. 3 & Exp. 4 & Exp. 1 & Exp. 2 & Exp. 3 & Exp. 4 \\
\hline & 一 & - & $15^{2}$ & 2 & 13 & 3 & 3 & 3 & 4 & 11 \\
\hline & - & aCD18 $\times$ aDNP & 40 & 6 & 37 & 9 & 7 & 3 & 5 & 13 \\
\hline & - & aClassI $\times$ aDNP & nt & 2 & 16 & 3 & nt & 1 & 4 & 11 \\
\hline $\mathrm{aCD} 3$ & $\times$ aDNP & - & 24 & 11 & 44 & 29 & 49 & 37 & 59 & 74 \\
\hline $\mathrm{aCD} 3$ & $\times$ aDNP & $\mathrm{aCD} 18 \times \mathrm{aDNP}$ & 42 & 31 & 70 & 56 & 49 & 46 & 69 & 76 \\
\hline $\mathrm{aCD} 3$ & $\times$ aDNP & aClassI $\times$ aDNP & $\mathrm{nt}$ & 12 & 40 & 23 & $\mathrm{nt}$ & 33 & 63 & 68 \\
\hline
\end{tabular}

Effector TCR $\gamma \delta^{+} / \mathrm{CD}^{+}$clone: WiK. ${ }^{1}$ Heteroconjugate concentration aCD3 $\times$ aDNP $=0.1 \mu \mathrm{g} / \mathrm{ml} ; \mathrm{aCD} 18 \times \mathrm{aDNP}=0.1 \mu \mathrm{g} / \mathrm{ml} ; \mathrm{aClassI} \times \mathrm{aDNP}=0.1 \mu \mathrm{g} / \mathrm{ml} .-^{2} \%$ specific lysis at an $E / T$ ratio of 24 .

TCR-mediated lysis at a post-conjugate stage. LFA-1-specific MAbs reportedly block lysis by CTL and NK cells through inhibition of conjugate formation (Makgoba et al., 1988a; Leo et al., 1987). Here we show that, although anti-CD18 MAb inhibited CD-3 mediated cytolysis by CTL of ICAM-1 - tumor cells, it did not affect their conjugate formation. These findings suggest that LFA-1 can transduce down-regulatory signals after conjugate formation, although the possibility that the inhibitory effect of anti-CD18 MAb is solely due to decreased recycling of CTL is to be formally excluded. A further argument in favor of a signalling function for LFA-1 comes from our previously reported observation that ICAM-1 - IgR39 tumor cells show a susceptibility to CD2-mediated lysis comparable to that of ICAM-1 ${ }^{+}$tumor cells (Goedegebuure et al., 1989). The relative resistance of ICAM-1 - target cells to CD3- but not CD2mediated lysis demonstrates that it is not merely due to a decreased conjugate-formating ability but suggests a signalling function for the LFA-1/ICAM-1 interaction. Hetero-crosslinked anti-CD18 MAb enhanced MHC-unrestricted lysis of the ICAM-1 - target cell by TCR $\gamma \delta^{+}$CTL but not by TCR $\alpha \beta^{+}$CTL in 2 out of 4 experiments. Still, LFA-1 crosslinking to the target cell per se is not sufficient to trigger the cytolytic machinery of TCR $\alpha \beta^{+}$and TCR $\gamma \delta^{+}$CTL because anti-LFA-1 MAb-expressing hybridomas, cross-linking LFA1, were not lysed by the CTL (Hoffman et al., 1985; unpublished observation). Hence, LFA-1 transduces a co-activation signal rather than a primary signal. Whether the functional interrelation between LFA-1 and the CD3/TCR complex de- pends on co-clustering of these molecules, as has been demonstrated for CD3/TCR and the accessory molecule CD4 (Saizawa et al., 1987), remains to be established.

In summary, our results demonstrate the central role of LFA1 in T-cell activation. LFA-1 appears to be involved in CD3/ TCR-mediated lysis at 3 distinct stages of the lytic cycle. Firstly, as known, it promotes binding of CTL to target cells; secondly, it delivers co-stimulatory signals to CD3/TCR in triggering cell-mediated lysis. Thirdly, it can transduce downregulatory signals after conjugate formation, i.e. anti-CD18 MAb inhibits CD3-mediated bispecific antibody-triggered lysis. Consequently, tumor cells lacking ICAM-1 expression may escape lysis by CTL. The relative resistance of ICAM-1tumor cells to lysis might be overcome by the induction of ICAM-1 on the tumor-cell surface, $e . g$. with TNF or IFN- $\gamma$ (Dustin et al., 1986). Also, the use of anti-CD2 $\times$ anti-target Abs which activate CTL independently of the additional LFA1/ICAM- 1 interaction or the combined use of bispecific antiCD3 $\times$ anti-target and anti-LFA-1 $\times$ anti-target Ab may induce efficient lysis of ICAM-1 - target cells.

\section{ACKNOWLEDGEMENTS}

The authors thank Miss B.A. van Krimpen for excellent technical assistance and Mrs. A. Sanders and Miss M. Drinkwaard for preparation of the manuscript. This study was supported by the Dutch Cancer Society "Koningin Wilhelmina Fonds", grants RRTI 85-13 and RRTI 85-17.

\section{REFERENCES}

Altmann, D.M., Hogg, N., Tronsdale, I. and Wilkinson, D., Cotransfection of ICAM-1 and HLA-DR reconstitutes human antigenpresenting cell function in mouse L cells. Nature (Lond.), 338, 512-514 (1989).

AsHWELL, J.D. and ScHWARTZ, R.H., T cell recognition of antigen and Ia molecule as a ternary complex. Nature (Lond.), 320, 176-179 (1986).

Barnstable, C.J., Bodmer, W.F., Brown, G., Galfrè, G., Milstein, C., Williams, A.F. and Ziegler, A., Production of monoclonal antibodies to group A erythrocytes, HLA and other human cell surface antigensnew tools for genetic analysis. Cell, 14, 9-20 (1978).

Billaud, M., Calender, A., Seigneurin, J.M. and Lenoir, G.N., LFA-1, LFA-3 and ICAM-1 expression in Burkitt's lymphoma. Lancet, II, 1327 (1987).

Bolhuis, R.L.H., Roozemond, R.C. and VAN DE GRIEND, R.J., Induction and blocking of cytolysis in $\mathrm{CD} 2{ }^{+} \mathrm{CD} 3^{-} \mathrm{NK}$ and $\mathrm{CD} 2+\mathrm{CD} 3+\mathrm{cy}-$ totoxic lymphocytes via CD2 $50-\mathrm{KD}$ sheep erythrocyte receptor. J. $\mathrm{Im}$ munol., 136, 3939-3944 (1986).

BOyd, A.W., WANRYK, S.O., BuRNS, G.F. and FeCONDO, I.V., Intercellular adhesion molecule 1 (ICAM-1) has a central role in cell-cell contact-mediated immune mechanisms. Proc. nat. Acad. Sci. (Wash.), 85, 3095-3099 (1988).

Clayberger, C., Wright, A., Medeiros, L.J., Koller, T.D., Link, M.P., SMITH, S.D., WARNKE, R.A. and KRENSKY, A.M., Absence of cell surface LFA-1 as a mechanism of escape from immunosurveillance. Lancet, II, 533-536 (1987).

DougherTy, G.J., Murdock, S. and HogG, N., The function of human intercellular adhesion molecule-1 (ICAM-1) in the generation of immune response. Europ. J. Immunol., 18, 35-39 (1988).
Dustin, M.L., Rothlein, R., Bhan, A.K., Dinarello, C.A. and SPRINGER, T.A., Induction by IL-1 and interferon, tissue distribution, biochemistry and function of a natural adherence molecule (ICAM-1). $J$. Immunol., 137, 245-254 (1986).

Dustin, M.L., Sanders, M.E., Shaw, S. and Springer, T.A., Purified lymphocyte function associated antigen 3 binds to $C D 2$ and mediates $T$ lymphocyte adhesion. J. exp. Med., 165, 677-692 (1987).

Goedegebuure, P.S., Segal, D.M., Braakman, E., Vreugdenhil, R.J., VAN KRIMPEN, B.A., VAN DE GRIEND, R.J. and BolHUIS, R.L.H., Induction of lysis by $\mathrm{TCR} \gamma \delta^{+} / \mathrm{CD} 3^{+} \mathrm{T}$ lymphocytes via $\mathrm{CD} 2$ requires triggering via the T11.1 epitope only. J. Immunol., 142, 1797-1802 (1989).

Gregory, C.D., Murray, R.J., Edwards, C.F. and Rickinson, A.B., Down regulation of cell adhesion molecules LFA-3 and ICAM- 1 in Epstein Barr virus positive Burkitt's lymphoma underlies tumor cell escape frorn virus-specific T cell surveillance. J. exp. Med., 167, 1811-1824 (1988a).

Gregory, C.D., Rickinson, A.B., de Rie, M.A., van SchiJndel, G.M.W. and MIEDEMA, F., Adhesion molecules, immunosurveillance, and B/cell malignancies. Lancet, I, 248 (1988b).

Hoffman, R.W., Bluestone, J.A., Leo, O. and Shaw, S., Lysis of anti-T3-bearing murine hybridoma cells by human allospecific cytotoxic $T$ cell clones and inhibition of that lysis by anti-T3 and anti-LFA-1 antibodies. J. Immunol., 135, 5-8 (1985).

Hunig, T., Tiefenthaler, G., Meyer zum Buschenfelde, K.-H. and MEUER, S.C., Alternative pathway activation of T cells by binding of CD2 to its cell-surface ligand. Nature (Lond.), 326, 298-301 (1987).

Karpovsky, B., Titus, J.A., Stephany, D.A. and Segal, D.M., Production of target-specific effector cells using heterocrosslinked aggregates 
containing anti-target cell and anti-Fcy receptor antibodies. J. exp. Med., 160, 1686-1701 (1984).

Keizer, G.D., VisSer, W., Vliem, M. and Figdor, C.G., A monoclonal antibody (NKI/L16) directed against a unique epitope on the $\alpha$-chain of human leukocyte function-associated antigen 1 induces homotypic cell-cell interactions. J. Immunol., 140, 1393-1400 (1988).

Krensky, A.M., SANCheZ-Madrid, F., Robbins, E., Nagy, J.A., SPRINGER, T.A. and BURAKOFF, S.J., The functional significance, distribution and structure of LFA-1, LFA-2 and LFA-3; cell surface antigens associated with CTL target interactions. J. Immunol., 131, 611-616 (1983).

Leo, O., Foo, M., Henkart, P.A., Perez, P., Shinohara, N., Segal, D.M. and BLuestone, J.A., Role of accessory molecules in signal transduction of cytolytic T lymphocyte by anti-T-cell receptor and anti-Ly-6.2C monoclonal antibodies. J. Immunol., 139, 3556-3563 (1987)

Makgoba, M.W., Sanders, M.E., Luce, G.E., Gugel, E.A., Dustin, M.L., SPRINGER, T.A. and SHAW, S., Functional evidence that intercellular adhesion molecule (ICAM-1) is a ligand for LFA-1 cytotoxic T cell recognition. Europ. J. Immunol., 18, 637-640 (1988a).

Makgoba, M.W., Sanders, M.E., Luce, G.E.C., Dustin, M.L., SPRINGER, T.A., Clark, E.A., MaNNONI, P. and Shaw, S., ICAM-1 a ligand for LFA-1 dependent adhesion of B-, T- and myeloid cells. Nature (Lond.), 331, 86-88 (1988b).

Marlin, S.D. and Springer, T.A., Purified intercellular adhesion molecule-1 (ICAM-1) is a ligand for lymphocyte function-associated antigen-1 (LFA-1). Cell, 51, 813-819 (1987).

MarTz, E., Mechanisms of specific tumor cell lysis by alloimmune T lymphocytes; resolution and characterization of discrete steps in the cellular interaction. Contemp. Top. Immunobiol., 7, 301-361 (1977).

MARTZ, E., LFA-1 and other accessory molecules functioning in adhesions of T and B lymphocytes. Hum. Immunol., 18, 3-37 (1987).

Mentzer, S.J., Smith, B.R., Barbosa, S.A., Crimmins, M.A.V., HerMANN S.H. and BURAKOFF, S.J., CTL adhesion and antigen recognition are discrete steps in the human CTL target cell interaction. J. Immunol., 138, 1325-1330 (1987).

Meuer, S.C., Hussey, R.E., FabBi, M., Fox, D., Acuto, O., FitzGERAl.d, K.A., Hodgdon, J.C., Piotentis, J.P., Schlossman, S.F. and REINHERZ, E.L., An alternative pathway of $T$ cell activation: a functional role for the 50KD CD2 sheep erythrocyte receptor protein. Cell, 36, 897906 (1984).

Miedema, F., Tetteroo, P.A.T., Hesselink, W.G., Werner, G., SPITS, H. and Melief, C.J.M., Both Fc receptors and lymphocytefunction associated antigen 1 on human Ty lymphocytes are required for antibody-dependent cellular cytotoxicity (killer cell activity). Europ. $J$. Immunol., 14, 518-523 (1984).

Mishra, G.C., Berton, M.T., Oliver, K.G., Krammer, P.H., Uhr, J.W. and VITETTA, E.S., A monoclonal anti-mouse LFA-1a antibody mimics the biological effects of B cell stimulatory factor-1 (BSF-1). $J$. Immunol., 137, 1590-1598 (1986).

Perez, P., Bluestone, J.A., Stephany, D.A. and Segal, D.M., Quantitative measurements of the specificity and kinetics of conjugate formation between cloned cytotoxic $T$ lymphocytes and splenic target cells by dual parameter flow cytometry. J. Immunol., 134, 478-485 (1985).

Pircher, H., Groscurth, P., Baumhutter, S., Aguet, M., ZinkerNAGEL, R.M. and HENGARTNER, H., A monoclonal antibody against altered LFA-1 induces proliferation and lymphokine release of cloned T cells. Europ. J. Immunol., 16, 172-179 (1986).

Rothlein, R., Dustin, M.L., Marlin, S.D. and Springer, T.A., A human intercellular adhesion molecule (ICAM)-1 distinct from LFA-1. $J$. Immunol., 137, 1270-1274 (1986).

SAIZAWA, K., RoJo, I. and JANEWAY, C.A., JR., Evidence for a physical association of CD4 and the CD3: $\alpha: \beta$ T-cell receptor. Nature (Lond.), 328, 260-263 (1987)

Schulz, T.F., MitTerer, M., Neumayer, H.P., Vogetseder, W. and DIERICH, M.P., Involvement in the initiation of $T$ cell responses and structural features of an $85 \mathrm{kDa}$ membrane activation antigen. Europ. $J$. Immunol., 18, 1253-1258 (1988).

Selvaraj, P.M., Plunkett, L., Dustin, M., Sanders, M.E., Shaw, S. and SPRINGER, T.A., The T lymphocyte glycoprotein CD2 binds the cell surface ligand LFA-3. Nature (Lond.), 326, 400-402 (1987)

Shaw, S., Luce, G.G., Quinones, R., Gress, R.E., Springer, T.A and SANDERS, M.E., Two antigen-independent adhesion pathways used by human cytotoxic T cell clones. Nature (Lond.), 323, 262-264 (1986).

Simmons, D., MaKgoba, M.W. and Seed, B., ICAM, an adhesion ligand of LFA-1, is homologous to the neural cell adhesion molecule NCAM Nature (Lond.), 331, 624-627 (1988).

Springer, T.A., Dustin, M.L., Kishimoto, T.K. and Marlin, S.D., The lymphocyte function-associated LFA-1, CD2 and LFA-3 molecule cell adhesion receptors of the immune system. Ann. Rev. Immun., 5, 223-252 (1987).

Staunton, D.E., Dustin, M.L. and Springer, T.A., Functional cloning of ICAM-2, a cell adhesion ligand for LFA-1 homologous to ICAM-1. Nature (Lond.), 339, 61-64 (1989).

Takai, Y., Reed, M., Burakoff S.J. and HermanN, S., Direct evidence for a receptor-ligand interaction between the $T$ cell surface antigen CD2 and lymphocyte function associated antigen 3. Proc. nat. Acad. Sci. (Wash.), 84, 6864-6868 (1987).

VAN DE GRIEND, R.J., Bol.hUIS, R.L.H., STOTER, G. and Roozemond R.C., Regulation of cytolytic activity in $\mathrm{CD}^{-}$and $\mathrm{CD}^{+}{ }^{+}$killer cell clones by monoclonal antibodies (anti-CD16, anti-CD2, anti-CD3) depends on subclass specificity of target cell IgG-FcR. J. Immunol., 138, 3137-3144 (1987).

Van Noesel, C., Miedema, F., Brouwer, M., de Rie, M.A., Aarden, L.A. and VAN LIER, R.A.W., Regulatory properties of LFA-1 $\alpha$ and $\beta$ chains in human $T$ lymphocyte activation. Nature (Lond.), 333, 850-852 (1988). 